\title{
A MEMÓRIA NA CONSTRUÇÃO DA IDENTIDADE CULTURAL EM DOIS IRMÃOS, DE MILTON HATOUM
}

\author{
Renan Augusto Ferreira BOLOGNIN* \\ Rejane Cristina ROCHA ${ }^{* *}$
}

\begin{abstract}
Resumo: Este artigo tem por objetivo discutir a maneira pela qual as estruturas do romance Dois Irmãos (2000), de Milton Hatoum, considerando-se a utilização delas como memorialísticas, evidencia identidades culturais entrechocando-se. O narrador-personagem, Nael, nos convida a conhecer um passado não inteiramente conhecido por ele, mas contado por outros personagens. Isto ocasiona uma diferenciação fragmentária não só do passado da narração e do presente da narrativa, mas também da posição ocupada por personagens no centro ou à margem da sociedade brasileira. Para estudarmos essas memórias como estruturas narrativas, embasamo-nos no Discurso da Narrativa (1995), de Gérard Genette. Já a fragmentação da ordem narrativa pelas memórias é discutida juntamente a questões relativas à fragmentação identitária. Para isso, apoiamo-nos n'A Identidade cultural na pós-modernidade, de Stuart Hall (2006).
\end{abstract}

Palavras-chave: Memória; Identidade Cultural; Literatura Brasileira Contemporânea.

\begin{abstract}
This paper focus on the way that the novel's structures Dois Irmãos, of Milton Hatoum, work in a recollection utilization and shows up the cultural identities knocking together. The narrator-character, Nael, invite us to a past didn't known for him, but that had been told it to him by other characters. This creates a fragmentary differentiation not just between narration past and narrative present, but also the occupied position for the characters in center or on the fringe of the Brazilian society. For studying these memories as narrative structures, we based our work on the Discurso da Narrativa (1995), of Gérard Genette. For its part, we discuss narrative order fragmentation for these memories related to the identity fragmentation. For that, we supported ourselves on A identidade cultural na pósmodernidade, of Stuart Hall (2006).
\end{abstract}

\section{Introdução}

Milton Hatoum, é um amazonense nascido aos 19 de agosto de 1952. Autor de obras conhecidas no cenário nacional e internacional, Milton Hatoum se destaca a priori pela capacidade de conquistar títulos literários. Entre eles, destaca-se o tri-Jabuti pelos romances Relato de um Certo Oriente (1989), Dois Irmãos (2000) e Cinzas do Norte (2002), que realçam a relevância e o esmero deste escritor contemporâneo. Além disso, ele publicou outras obras, que assumiram até o presente momento menor prestígio acadêmico, embora não nos pareçam de menor qualidade literária. Referimo-nos, nesse ponto, às três últimas obras do escritor: Órfãos do Eldorado (2008), A Cidade Ilhada (2009) e Um solitário à espreita (2013).

\footnotetext{
* Mestrando do Programa de Pós-Graduação em Estudos de Literatura (PPGLit) da Universidade Federal de São Carlos. Bolsista FAPESP. E-mail: renanbolognin@ hotmail.com.

** Docente do Programa de Pós-Graduação em Estudos de Literatura (PPGLit) da Universidade Federal de São Carlos (UFSCar). E-mail: rjncris@gmail.com.
} 
Durante a juventude, Hatoum estudou no Colégio de Aplicação da UNB, em Brasília, quando para lá se mudou em 1967. Cursou Arquitetura e Urbanismo na USP e, posteriormente, exerceu as profissões de jornalista cultural e professor universitário de História da Arquitetura. Através de uma bolsa angariada, durante os anos 80, teve a oportunidade de conhecer as cidades de Madri e Barcelona e estudar Literatura Comparada na universidade de Sorbonne (Paris III).

O narrador de Dois Irmãos (2007) (DI), de Milton Hatoum, é Nael, filho da indígena Domingas. Ambos são agregados de uma família de libaneses, encabeçada por Halim e Zana. Do casamento deles nasceram: Nael, Yaqub (gêmeos que intitulam o romance) e Rânia. Da ambígua relação de subserviência e intimidade familiar erige-se um mistério: seria um dos gêmeos o pai de Nael?

Para responder a este mistério, Nael segue pelos tortuosos caminhos do passado, aproveitando histórias que outros personagens lhe contaram. Afinal, conhecer a origem delas é análogo a conhecer a si mesmo. Por isso, Nael volta ao passado muitas vezes, aproveitando-se das histórias que outros personagens lhe contaram a respeito do passado familiar, enquanto por outras faz o leitor perceber que ele narra desde um lugar avançado temporalmente em relação ao contado. Deste modo, apresenta-nos a Galib, que viveu no Brasil antes de seu nascimento, pai de Zana e bisavô de Nael. Na sequência, conhecemos a respeito do romance entre Zana e Halim quando jovens, depois da inserção da indígena Domingas na família e o nascimento dos gêmeos e Rânia. Da segunda geração da família, acompanhamos o crescimento de Omar e Yaqub e a disputa de ambos pelo amor de Lívia, que resultaria no exílio forçado no Líbano do conquistador do coração dela, no caso o segundo. Após o regresso de Yaqub ao Brasil, Nael já era nascido, fruto de uma bebedeira de Omar e consequente estupro da agregada Domingas. Daí, surge o interesse do narrador em conhecer a história da família como história de si mesmo, sem deixar de relatar a convivência com a família libanesa até sua consequente ruína, tanto da casa que os abrigava - da qual resta a Nael um puxadinho como herança -, quanto referente à morte dos patriarcas e dissolução dos laços fraternos que, supostamente, uniriam os filhos.

Assim, o tempo da narrativa embaralha-se com o do discurso: Nael, como narrador, não é o mesmo garoto que vivera a infância entre os libaneses. Nas memórias familiares e pessoais contadas por ele há movimentos construídos "horizontalmente", concernentes ao percurso cronológico, e "verticalmente" (PELLEGRINI, 2004, p. 123), das inconclusões do passado em que a imaginação tenta refazer o desconhecido. Esses movimentos memorialísticos, objetivos e subjetivos, são evidenciados por Beatriz Sarlo (2007) a partir da concepção de que: “[...] a narração inscreve a 
experiência numa temporalidade que não é a de seu acontecer, mas a de sua lembrança (p. 25)". Isto é, há um corte na experiência quando a associamos ao acontecimento e quando a relacionamos à sua lembrança. Embora ambos, acontecimento e lembrança, pareçam semelhantes e tratarem do mesmo fato, a narração colore o passado com as cores do presente.

Avançando um pouco, nos damos conta de que o passado narrado é prenhe da perspectiva de seu narrador. E, por narrar sobre si mesmo, Nael permite que adentremos no conceito de identidade, pois as memórias familiares e próprias são basilares na constituição dele, auxiliando-o na identificação com o 'outro' ao dar-se conta do lugar social que ele, agregado e não familiar, ocupa.

Assim, memória e identidade não correspondem apenas ao resgate de um passado individual, mas também ao de outros personagens. Isso equivale, narratologicamente, a um entretecer de discursos (direto, transposto e narrativizado) do qual tanto a importância de ser responsável por trazer à tona a origem da família de libaneses, quanto o sentido de permitir a visualização de vozes que tentam se descolar da margem social, vem à tona no discurso.

Neste caso de recomposição discursiva, de entretecer de discursos, as memórias dos personagens atam em círculos concêntricos a identidade individual e a cultural. Eles são evidenciados nos movimentos de entretecimentos da narração, no caso no tempo da história, do discurso, no estatuto do narrador e na focalização. No primeiro e no segundo, tempo da história e do discurso, o leitor acompanha a internalização de Nael e a externalização ao passado familiar. Em linhas gerais, a busca da identidade na origem da própria família. No estatuto do narrador, damonos conta de um deslizamento de categorias, representando, por fim, a própria identidade escorregadia de ser membro e empregado da própria família. Por fim, a focalização, instrumental narratológico através do qual o narrador diz qualitativamente e quantitativamente sobre a história contada a partir de um lugar social que o impele a contá-la de uma maneira e não de outra.

Deste modo, memória e identidade cultural subscrevem-se na narração e, por conseguinte, representam um caráter social que permite-nos conjecturar alguns significados histórico-sociais.

Neste sentido, versaremos sobre as confluências de memórias no tempo do discurso e da narrativa juntamente ao narrador e seus interesses de unificar o passado no presente e quais as consequências identitárias na primeira seção deste artigo enquanto seção, principalmente, de nosso embasamento teórico. Na sequência, afunilaremos a questão identitária por intermédio da voz de Nael como sintomática da vinda à tona das vozes menosprezadas ao centro. 


\section{Memória e Identidade Cultural}

A memória é um conceito amplamente explorado ao longo dos séculos. Por haver diversas maneiras de tratá-la, Paolo Rossi (2007) a situa presente desde correntes filosóficas a estudos de cunho biológico. De alguma maneira, ela, memória, não deixa de ser um processo requerente de pertença ao passado, como ele aponta: “A memória faz que os dados caibam em esquemas conceituais, reconfigura sempre o passado tendo por base as exigências do presente (pp. 28)". Assim sendo, ela não ocorre do nada, pois por trás dela há interesses de se trazer o passado de volta no discurso do presente. Sendo assim, ela não conta do passado em sua inteireza, mas baseia-se nele para criar uma história diferente do fato inicial.

Ainda segundo Paolo Rossi (2007, p. 15-16) Aristóteles nos explica melhor o dito anteriormente, pois ele mencionava a memória como precedente à reminiscência e presente no mesmo lócus da imaginação. O filósofo grego também ressalta o caráter relacional da memória como uma coleção de imagens, acrescidas de interpretação. Ou seja, a memória é do passado (RICEUR, 2007) e indica um período interpretado criativamente pelo recordador.

Este pressuposto remete ao narrador de DI: as memórias narradas por Nael também estão fartas de interpretações dele. Somado isso ao caráter autobiográfico ficcional da obra, a tentativa de construção identitária é notória. Em DI, a memória é tomada pelo narrador por interesses próprios. Como ele é o responsável pela sua narrativização, sugere um apelo a um processo infinito de escrita de si.

Portanto, as recordações de Nael estão repletas de interpretações, que fragmentam a ordem narrativa devido ao acréscimo de memórias alheias que rompem a ordem linear dos acontecimentos do romance. Já nos procedimentos narrativos de focalização e no estatuto narrativo - que diz respeito ao narrador ser auto, hetero ou homodiegético - a tentativa de construção identitária fica mais evidenciada. Narratologicamente, os relatos ocorrem a partir dos discursos alheios, tratados por Genette (1975) como diretos, transpostos e narrativizados. Estes discursos demonstram que nem sempre as memórias são individuais: são sociais devido ao diálogo existente entre o dizer alheio e o próprio. Ao narrar uma memória alheia - uma não experiência - Nael a profana já que ela se desloca interna e externamente sobre quem a conta e quem a viveu. Portanto, um deslocamento que não é só de perspectiva, mas também de cronologia.

Deslizar pelas memórias, do passado ao futuro, é valorizar o senso-comum de que conhecendo-se o passado entende-se o futuro. No caso, a escrita desse passado visa à conservação dos acontecimentos, individuais ou coletivos, e tem motivação: 
Tornar-se senhores da memória e do esquecimento é uma das grandes preocupações das classes, dos grupos, dos indivíduos que dominaram e dominam as sociedades históricas. Os esquecimentos e os silêncios da história são reveladores destes mecanismos de manipulação da memória coletiva (LE GOFF, 2003, p. 422).

Tornar-se senhor do passado é refletido na organização da narrativa de Nael. As experiências alheias incidem diretamente na configuração da identidade do agregado, que busca os cacos do passado que o (re) componham. Assim, este passado é também coletivo, pois o 'outro' pode identificar-se nessas memórias, pois elas, em seu âmago, são também alheias. Como resultado, essas memórias são um jogo infinito de deslocamentos e aproximações entre identidades distintas.

As alternâncias temporais operacionalizadas pelo narrador são a manifestação de um vaivém de tempos narrativos como matriz da cicatriz identitária, entre experiência e não experiência, pois a identidade não tem apenas um significado que a delimite. Seu matiz semântico está entre o 'eu', o 'ele' e a cultura na qual ambos estão inseridos ou na cultura na qual ambos se identificam ou não.

Enquanto romance, em DI fica evidente que a identidade passa pelo crivo da narração, pois é nela que é enunciada. Ela está submersa nos dizeres do narrador e vem à tona quando nos damos conta de que Nael está inserido num lugar cultural que o trespassa, no caso de sua origem híbrida, afinal é filho do estupro da indígena Domingas por Omar, descendente libanês; brasileiro; manauara; curumim (filho de uma indígena); e, por tudo isso, é dependente das histórias de sua família, ainda que tratado como subserviente.

Unir o passado ao presente da narração demonstra a confusão entre identidade e memória no nível narrativo: “O homem nunca coincide consigo mesmo. A ele não se pode aplicar a forma de identidade: A é idêntico a A (BAKHTIN, 1981, p. 50)". A disposição narrativa sugere procedimentos de identificação e pertencimento (HALL, 2006) entre a voz, o narrado por ela e o personagem, pois a voz do 'outro' auxilia na constante formação do 'eu'. Assim, a escrita valorizase como tentativa de permanência de uma identidade através de uma história. Ou seja, Nael escreve uma história e deseja que ela permaneça no tempo e lhe constitua como autor de si mesmo.

Para se falar do 'eu', do 'aqui' e do 'agora', ou seja, do espaço cultural de onde o narrador enuncia, o movimento é, primeiramente, linguístico. Bakhtin (1981) demonstra que este não é um movimento irrelevante do ponto de vista ideológico, pois as vozes componentes dos tecidos romanescos são uma cadeia política ancorada na esteira do espaço sociocultural.

Em DI, a diferença entre o narrador e a família é demonstrada pelos contrastes que o separam dos demais membros. E a estrutura textual representa essas diluídas relações de aproximação entre empregados e patrões em nossa sociedade, como sugere: "Foi Domingas quem 
me contou a história da cicatriz no rosto de Yaqub (HATOUM, 2007, p. 20)" enquanto aproximação horizontal entre empregados. Por sua vez, Nael enquanto neto de Zana “(...) só existia como rastro dos filhos dela" (HATOUM, 2007, p. 28). Já a presença de Domingas, nunca foi fator impeditivo nem para a vida sexual dos patrões: "Ela se assustava com o estardalhaço que os patrões faziam na hora do amor, e se impressionava como Zana, tão devota, se entregava com tanta fúria (HATOUM, 2007, p. 48)".

Em todas essas memórias diluídas da família emergem relações que põem ênfase nas aproximações e distanciamentos a partir de algum interesse dos patrões. Contar sobre Yaqub é contar sobre o mártir da família. Assim mesmo, Nael não é reconhecido nem pela própria avó, uma mulher que nem ao menos se incomoda com os julgamentos que os agregados de sua casa tecerão ao entregar-se libidinosamente de maneira indiscreta. É, portanto, na colagem de fragmentos como esses que percebemos as aproximações de empregados com a vida de seus 'patrões'. Releva-se que em Nael essas vozes postas à margem de nossa sociedade começam a exigir atenção. Logo, o narrador e os demais personagens representam algo além de uma identidade e a busca de sua unicidade. Como suas identidades estão em choque paulatino em trechos como esses, elas acabam sendo postas em confronto umas com as 'outras'.

Deste modo, as identidades entram em contato não só com o ponto de vista de Nael. A partir do momento em que a voz do narrador se confunde com a de outros personagens, a focalização escorrega da interioridade para a exterioridade, fundindo nesse mágico movimento narrativo a cultura, o período histórico e o espaço do 'outro' com as percepções do 'eu’ da narração: “Cego de amor, até as últimas. Pobre Halim! Pobre? Nem tanto. Um guloso de amor carnal: fez da vidinha na província uma festa de prazeres (HATOUM, 2007, p. 127)” acerca de como o extravasamento sentimental de Halim por Zana é visto por Nael. É uma movimentação que, se não resolve a impossibilidade do contato com o passado, ao menos representa a tentativa de interlocução por meio da busca pelas origens. No caso, Nael não deixa de ser fruto do guloso amor carnal do casal.

Para Bauman (2003), a identidade no período moderno se funde aos conceitos de durabilidade, solidez. Já no período contemporâneo, ele enxerga a identidade formada por uma gama imensa de valores não permanentes. A palavra do 'outro' aparece imiscuída nos discursos do narrador, fazendo-se palavra dele. O contato entre essas vozes é a identidade, mostrando-se 'líquida' e escorregando de um lado a outro durante a leitura do romance.

Por isso, partimos do princípio de que toda voz seja política. Portanto, dentro das veias temporais desse romance corre um sangue político. Embora na voz de outros que as contam, tais 
identidades não fogem da necessidade de expandir-se no contato com o 'outro'. Tanto é que ele e sua família não possuem um sobrenome:

Decerto, os nomes também podem transmitir algumas informações de caráter social: a região de origem, o sexo, o grupo étnico, a condição econômica, ou até (no caso dos nomes de batismo) as ambições sociais ou a história familiar (GALLAGHER, 2009, p. 647).

O sobrenome (ou nome) é um conceito indicador das origens. Uma espécie de gene social. No entanto, a família libanesa não possui um. Correlativamente, não possui voz política. Por um lado, isso indica que a importância da família parece pequena, afinal são seres (praticamente) anônimos. Por outro, indica que os socialmente marginalizados vêm à tona, pois suas identidades culturais clamam que suas vozes sejam ouvidas. Por conseguinte, clamam por espaço na voz política.

Em DI isso se assemelha metonimicamente ao mito da origem de uma nação e da estruturação familiar, decorrendo na modelação da subjetividade de Nael. Nele, é evidente a necessidade de encontrar o princípio de si mesmo na origem familiar. Nael demonstra que as identidades são situações relacionadas ao tempo e, por isso, uma pesquisa é necessária para entender a qual grupo pertence.

E esse interesse pela origem surge potentemente a partir da história do Biblos:

Por volta de 1914, Galib inaugurou o restaurante Biblos no térreo da casa. O almoço era servido às onze, comida simples, mas com sabor raro. (...) Desde a inauguração o Biblos foi um ponto de encontro de imigrantes libaneses, sírios e judeus marroquinos que moravam na praça Nossa Senhora dos Remédios e nos quarteirões que a rodeavam (HATOUM, 2007, p. 36 , grifos do autor).

A gênese de Nael remonta à de seus antepassados e estabelecimento em Manaus. Conhecelos é sinônimo de conhecer-se, fincando-se num determinado grupo cultural que o estabeleça, no caso o dos imigrantes. Essa é a pesquisa de Nael, que nos segreda:

Eu não sabia nada de mim, como vim ao mundo, de onde tinha vindo. Meu passado, de alguma forma palpitando na vida dos meus antepassados, nada disso eu sabia. Minha infância, sem nenhum sinal de origem (HATOUM, 2007, p. 54, grifos do autor).

Evidencia-se, assim, a busca da identidade cultural mediante a construção do passado familiar. Sobretudo suas diferenças com a família, enquanto subalterno, podem ser percebidas a partir da consideração da identidade cultural como signo. Ela, identidade cultural, é ideológica como todo signo, pois é impossível dissociá-la de um significado e de um significante.

Nael está inscrito numa identidade subalterna, marginal, - que parece expandir-se - e a malha político-social da qual faz parte brada por este interesse e o demonstra claramente mediante as organizações estruturais do texto, a voz e sua focalização que deflagram o tecido sócio histórico, 
o extralinguístico. Nael representa, pois, o olhar invertido das identidades hegemônicas. É o diatópico.

Identificar-se com sua própria condição não é (apenas) uma liberdade individual. Isso está ancorado na esteira da história precedente. Para Nael viver sua própria vida e conhecer-se, a busca das memórias familiares demonstra que qualquer um está condicionado a pertencer a (uma) cultura(s), identidade e local (ou comunidade) que é posta necessariamente em contraste com outra tal como Stuart Hall (2003) explicita:

Uma identidade cultural particular não pode ser definida apenas por sua presença positiva e conteúdo. Todos os termos da identidade dependem do estabelecimento de limites definindo o que são em relação ao que não são. [...] Toda identidade é construída sobre uma exclusão e, nesse sentido, é "um efeito do poder" (p. 85).

E Nael demonstra sua identidade como uma relação não gratuita entre aquilo ao qual ele quer pertencer e o desejo de sentir-se pertencido. Ao identificar-se com determinados fatos da família, ele demonstra-se indiferente a outros que nem foram narrados, afinal toda narração possui uma seleção dos argumentos imprescindíveis. De um lado, a voz social - no caso a dos marginalizados socialmente - vem à tona - enquanto a outra - a dos patrões, dos chefes de famílias aristocráticas de sobrenomes importantes - é esmagada pela primeira.

Nessa experiência da memória, que proporciona o desenrolar de um tema, Nael vê sua constituição e passado entrechocados. Ele se dá conta de que não é o mesmo de outrora: o eu exterior é diferente do que ele idealiza enquanto autorretrato. Conforme diz Paul Ricœur (1995, p. 30): “O sujeito [...] não se conhece a si mesmo diretamente, mas só por meio dos signos depositados em sua memória e em seu imaginário pelas grandes culturas (apud Bertrand, 2003, p. 22)”.

O sujeito não conhece a si mesmo, pois ele é e também 'está sendo'. Sua unicidade reside na tentativa de encontrar-se. Sua multiplicidade reside num sem-fim de indefinições. A identidade, portanto, nunca poderá ser resolvida. É um narcisismo. A identidade existe por si a partir de como o 'outro' forma o 'eu' e vice-versa. Nesse contato, ganha relevância a coletividade. Algum fermento social faz com que a atitude de um possa ser vista como a de um conjunto, que é como a voz de Nael será posta na sequência.

\section{Nael: um maestro marginal}

A história contada por Nael é borrada. Detém tempos sobrepostos uns nos outros e enunciadores indeterminados. O passado é remontado discursivamente, tangendo a impossibilidade da representação. Isto é: as memórias do narrador e das personagens são, enunciativamente falando, distintas (SARLO, 2007) por conta do que a passagem do tempo representa para o personagem. Isso 
porque as memórias adquiriram perquirições, julgamentos, reflexões, pensamentos, imaginações, etc. em relação a como o recordador as narra a partir de sua condição presente. Entretanto, elas não perderam sua essência: há ainda um fio condutor que dá coesão e coerência para serem enunciadas.

Como fatores de ressignificação das memórias estão incluídos a compactação delas em uma única voz e os vestígios dos que as experimentaram e depois as contaram a Nael:

E para isso", dizia o pai, orgulhoso, "não é preciso língua, só cabeça. Yaqub tem de sobra o que falta no outro. Omar ouvia essa frase e tornou a ouvi-la anos depois, quando Yaqub, em São Paulo, comunicou à família que havia ingressado na Escola Politécnica [...] (HATOUM, 2007, p. 25, Grifo nosso).

As alternâncias de instâncias narrativas articulam-se a ponto de tornarem-se quase imperceptíveis. O fragmento acima mostra que as certezas de Halim no passado confirmam-se no futuro da narrativa. Um passado, deste modo, quase obliterado, pois encontramos a voz de Halim na de Nael quase que imperceptivelmente. Neste testemunho, as barreiras entre ouvinte da memória familiar e espectador dos fatos parecem borrar-se, como nos apontamentos de Sylvia Telarolli (2010):

Não coincide também aqui, como no Relato de um certo oriente, o tempo da história, já passada, com o tempo da narração; por isso, são difusas, nebulosas, as lembranças do narrador, que agora adulto regressa ao passado [...]. A eleição do narrador homodiegético é bastante oportuna para o desenvolvimento da narrativa em questão (p. 3).

Às experiências de Nael subjazem as vivências com os libaneses. Ou seja, o protagonismo lhe é negado, ainda que ele seja o responsável pela narração do passado familiar. O tecido híbrido de tempos memoriais comprova que ele segue a narração em paralelo à condição de agregado, afinal o protagonismo é destinado, até no nome do romance, aos irmãos.

Por isso mesmo, o primeiro passo para caracterizar o estatuto de Nael diria respeito aos discursos alheios. No princípio do romance, a narração dá a impressão de que poder-se-ia configurá-lo como extradiegético, pois a existência de tempos anteriores ao nascimento de Nael abre alternativas para narrações, aparentemente, 'desapaixonadas' em terceira pessoa.

O segundo diz respeito às experiências vividas por Nael. Ele assina o romance na marginalidade, no quartinho dos fundos da casa dos libaneses. Assim, o estatuto homodiegético lhe cai bem, mesmo que haja resquícios do autodiegético.

Como relevantes da tomada de voz de Nael, interessa também como a narração memorialística faz com que os conceitos extensos do passado caibam em pequenos dados equivalentes à importância do contado. À duração (ou velocidade) dos eventos narrativos, através do encaixe de memórias na narração, compara-se o tamanho dos capítulos. Damo-nos conta de que 
os capítulos possuidores de maior extensão de páginas são os mais distantes ao presente da narração, ou seja, os que mais se utilizam de memórias. Por sua vez, os de menor extensão são aqueles em que o narrador mais se aproxima do presente da narrativa, o que sugere a menor importância dessa voz que, no entanto, é o leitmotiv da busca do passado. Assim, os capítulos que possuem o maior número de páginas na obra são: o $1^{\circ}, 4^{\circ}, 5^{\circ}, 6^{\circ}, 7^{\circ}$ e $8^{\circ}$, enquanto os demais do romance possuem menor extensão. Se por um lado, parece haver menor importância na voz de Nael, por outro, o mais relevante, damo-nos conta de que como ele é o responsável por narrar todo este imbróglio narrativo, também será ele o maior usufruidor do passado contado e, consequentemente, um maestro marginal, que esconde sua voz e, apesar de cantar baixo, é o responsável por conduzir um coro de vozes até seu derradeiro final.

Para esclarecer isso, cabe mencionar a origem da rivalidade dos irmãos:

A magia no porão durou uns vinte minutos. Uma pane no gerador apagou as imagens, alguém abriu uma janela e a platéia viu os lábios de Lívia grudados no rosto de Yaqub. Depois, o barulho de cadeiras atiradas no chão e o estouro de uma garrafa estilhaçada, e a estocada certeira rápida e furiosa do Caçula. $\mathrm{O}$ silêncio durou uns segundos. E então o grito de pânico de Lívia ao olhar o rosto rasgado de Yaqub. (HATOUM, 2007, p. 22)

O tempo necessário para que este fato ocorresse tem uma velocidade maior na narrativa. No entanto, este acontecimento é relevante a Nael por ser o diferenciador: seu pai não poderia ser Yaqub, afinal este era apaixonado por Lívia desde garoto. A cicatriz no rosto do tio Yaqub é a marca de Nael: Afinal, o filho então deportado para o Líbano será o que mais se identificará com o agregado pela própria família. A história de Nael converte-se, também, na história do filho esquecido, pois, de alguma maneira, ambos são esquecidos e colocados à margem.

Da compactação desta memória chegamos à explosão: a agressão a Yaqub foi bem mais ligeira do que as linhas que a contam. No duelo travado entre rapidez/ lentidão, começamos a notar quando se trata de algo que Nael (não) presenciou. Trata-se de algo que: "Domingas me contou (HATOUM, 2007, 23)" muitas vezes. Noutras, chama a atenção uma cena presenciado por Nael, a mais atraente do romance:

Um muro alto e sólido separava o meu canto da Casa Rochiram. Ele ousou e veio avançando, os pés descalços no aguaçal. Um homem de meia-idade, o Caçula. E já quase velho. Ele me encarou. Eu esperei. Queria que ele confessasse a desonra, a humilhação. Uma palavra bastava, uma só. O perdão. Omar titubeou. Olhou para mim, emudecido. Assim ficou por um tempo, o olhar cortando a chuva e a janela, para além de qualquer ângulo ou ponto fixo. Era um olhar à deriva. Depois recuou lentamente, deu as costas e foi embora. (HATOUM, 2007, p. 198)

Este foi o último contato de Nael com o "pai” Omar. Embora o curumim tenha sido o último a integrar-se à família, foi o único a receber um cômodo da casa, que lhe fora concedido 
como herança após a dívida contraída pela família com o indiano Rochiram. Há uma pausa angustiante neste trecho. Nael focaliza o olhar titubeante de Omar externamente, enquanto a focalização interna desdobra-se para o emudecimento deste. A esperança recai no perdão de Omar, na tentativa de descosturar os fios mal remendados, e tecer com o outro as inconclusões do passado com os fios da verdade. Na verdade, um duelo mudo entre as vozes postas à margem e as do centro. Um duelo irresoluto, no qual o perdão cai no esquecimento voluntariamente. Por tantas inconclusões, os acordes do passado e a duração deles receberam a interpretação do maestro Nael. À velocidade desse trecho opõe-se uma pormenorização que pretende mostrar ao leitor o desejo contido pelo perdão de Omar. Guardadas as devidas proporções, este trecho indica que a margem espera o perdão do centro.

Da mesma forma, a ordem dos acontecimentos, também, não segue uma correspondência linear:

QUANDO YAQUB VOLTOU DO LÍBANO, o pai foi buscá-lo no Rio de Janeiro. O cais da praça Mauá estava apinhado de parentes de pracinhas e oficiais que regressavam da Itália. Bandeiras brasileiras enfeitavam o balcão e as janelas dos apartamentos e casas, rojões espocavam no céu, e para onde o pai olhava havia sinais de vitória. (HATOUM, 2007, p. 11, grifos do autor)

A volta de Yaqub ao Brasil é posterior à chegada de Zana e/ou Halim ao país, embora seja narrada anteriormente ao estabelecimento deles em Manaus. Ambos os conteúdos são memorialísticos, contudo não são narrados linearmente. Notando esta recorrente "desordem" no romance, percebe-se a fragmentação da estrutura narrativa pelas memórias.

Esquecer o lugarejo no Líbano em que vivera é tarefa impossível para Yaqub. Ao regressar, a cicatriz que carrega no rosto corporifica a recordação, mas não deixa de ser representada na fragmentação dos episódios narrativos. Isto é, a vida de Nael depende diretamente desse acontecimento narrativo que cingiu a família de libaneses. À narração cabe a função de cicatrizá-la. No entanto, esta é uma impossibilidade aparente, pois após a ida de Yaqub ao Líbano este será o filho posto à margem.

Quando Nael assume posicionamentos homodiegéticos mais claros, isto é, quando passamos a notá-lo como intradiegético, a narração aproxima-se de sua interioridade e o uso do movimento interno/ externo desta mesma focalização faz uso da fertilidade do terreno memorialístico. Como sentido da memória, ao narrador é difícil afirmar o que aconteceu no passado que lhe foi contado. A narrativização e a transposição de discursos desempenham um papel de slow motion na narrativa. Por isso, Nael precisa causar a impressão, com um pernóstico detalhamento, de que conhece 
integralmente o passado familiar. Noutros casos, não se aprofunda em tantos detalhes quando relata algo experimentado por ele:

Foi nessa época que me afastei de Rânia. Eu não queria. Gostava dela, era atraído pelo contraste de uma mulher assim, tão humana e tão fora do mundo, tão etérea e tão ambiciosa ao mesmo tempo. As lembranças da noite que passamos juntos, o ardor daquele encontro ainda me davam arrepios (HATOUM, 2007, p. 195).

A aproximação de Nael como narrador e como personagem é elucidada acima. $\mathrm{O}$ curumim se consome em desejos pela tia Rânia, recordando-se dos momentos sexuais efêmeros vividos com ela, das "lembranças da noite". A velocidade decai e a memória traveste o passado alheio com os paradoxais e apaixonantes adjetivos "etéreo" e "ambicioso", dedicados à tia.

Nael traz essas recordações como recordações de uma noite amorosa inesquecível na qual o incesto com a tia desloca-se para a paixão de uma noite. Desta mesma forma, ele também tenta se deslocar, afinal é desde sempre um sujeito deslocado socialmente pela própria família. Ainda que haja tido uma relação com Rânia, isso não lhe tira o papel de subserviente, pois ela deita-se com o funcionário, não com o sobrinho.

E como esta voz de Nael é periférica, marginal, nos remete à lembrança de que Halim não queria ser pai: “Alguns dos nossos desejos só se cumprem no outro, os pesadelos pertencem a nós mesmos (HATOUM, 2007, p. 196)". Uma experiência vivida pelo patriarca na mocidade e narrada por um sujeito que vive no fundo da casa. Domingas, Zana, Halim, Yaqub, Omar, Rânia e Nael formam o septeto do romance. Cabe a Nael reger, ardilosamente, tais vozes. Curiosamente, um agregado bastardo circunscrito entre empregado e membro da família, e em busca de sua identidade, articula o enredo. Como maestro, Nael demonstra capacidade de incorporar vozes à própria, ainda que esteja hierarquicamente abaixo delas. O ponto de vista dele é, indubitavelmente, diferente de como a mesma história seria contada pelos patrões.

Por isso, falta muito para orquestrá-las com perfeição, pois:

A retomada da memória individual, cruzada com a memória coletiva, do clã, equaciona no romance de Milton Hatoum esse dilema de modo distinto, apostando na possibilidade de que a palavra assuma a feição de resgate de parte dessa experiência, ainda que não de modo pleno (CHIARELLI, 2007, p. 43).

O resgate da memória do clã familiar é tendenciosamente contado no cruzamento com os diversos pontos de vista do narrador. É um hibridismo focalizador, difícil de notar, impossível de resolver. Sob a égide de Nael as memórias são deslocadas do centro para a margem. As redes de memórias mescladas evidenciam a voz de Nael agregada a outras. Neste modo peculiar de narrar, a narrativa insere-se numa trama complexa não só de vozes, mas também de identidades que se 
pretende "juntar". O manauara Nael é contornado não só pelos pontos de vista das histórias ouvidas: a elas são agregadas experiências identitárias dos demais, posicionando-o num vasto campo de identificações (entre ser libanês, indígena, brasileiro, etc.), cujo pertencimento é levado ao inconcluso.

Analogamente, tal construção identitária é demonstrada em Yaqub:

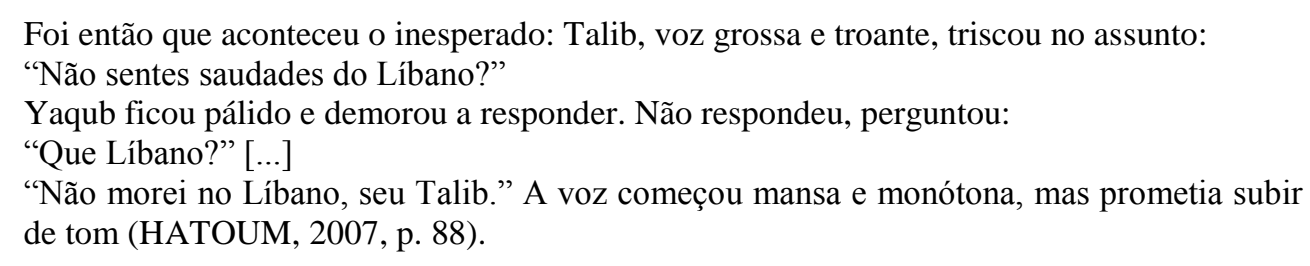

Yaqub não se identifica com o Líbano. Ele recusa o pertencimento. E permanecendo calado não dá vazão a interpretações. A memória dele opera pelo esquecimento impossibilitado da recordação indesejada. Alheia ao personagem, tal falta de identificação passa pelos jogos restritivos do narrador, além da distância a separar sua memória da colocação de tal cena no papel. Cabe à voz do sobrinho bastardo e pobre, narrar a respeito dos problemas identitários do tio libanês.

Yaqub responsabiliza-se pelo fim do encadeamento de memórias: a cicatriz do passado estampada no rosto mobiliza apenas memórias dele mesmo. O entrelaçamento com as memórias de Nael é impossibilitado e finca-se a incompletude na narrativa.

Caso fosse desejo do narrador, ele poderia narrar a respeito de Yaqub no Líbano, mas isso seria um acréscimo à sua qualidade de conhecedor do passado. Demonstrar acréscimos sobre o que não sabe seria uma evidência ao leitor de que ele não manipula uma história conhecida integralmente. Com isso, Nael somente pode ter condolência do passado do tio, mas não narrá-lo. A dor da recordação restringe-se ao rosto de Yaqub.

Se o ponto de vista do narrador é impedido de trabalhar nesta recordação, ao menos notamos uma interessante identificação entre Nael e Yaqub. Se Omar é o pai, ou tio (pois a identidade familiar também está deslocada), Yaqub é o mensageiro dos progressos de São Paulo.

Esta mescla identitária ganha valor com a inserção de uma seringueira, árvore manauara, no centro da cidade de São Paulo (HATOUM, 2007, p. 4). É a demonstração da chegada do marginal ao centro: a cidade política e economicamente atrasada ganha destaque na relação com o polo industrial do país.

Da mesma forma, não é do filho centro das atenções, Omar, de quem Nael terá mais atenção, mas do esquecido no Líbano. Um jogo de identificações entre subjetividades, ainda que opostas. Yaqub não quer saber da "historinha passada de boca em boca", obstruindo o fluxo dessas 
memórias. Nael prefere escrever, enquanto Yaqub é o gênio das exatas. São diferentes modos de pensar embrenhando-se numa voz que não chega à completude do narrado. São identidades jogadas à margem que se mesclam sugerindo que, numa relação contextual, a voz dos marginalizados socialmente clama ser ouvida. E clama, democraticamente, lugar de destaque na história por meio de memórias.

\section{Considerações finais}

A utilização da memória é uma busca das origens, pessoais e sociais. Logo, a origem individual recai na identidade cultural. Como social, a origem é uma busca híbrida, que, pela voz do narrador, deixa entrever a formação híbrida sob a qual se ancora nossa cultura e nacionalidade brasileiras. Mesclando subserviência com intimidade na própria família - uma das bases de nossas relações trabalhistas, segundo Antonio Candido (1989) - o agregado Nael conta uma história à margem. Resultante da relação deste texto com o contexto contemporâneo, a voz de Nael é percebida como a vinda à tona de vozes subalternas que querem ser ouvidas e exigem seu lugar de direito na democracia.

\section{Referências}

BAKHTIN, Mikhail. Problemas da poética de Dostoievski. Trad. de Paulo Bezerra. Rio de Janeiro: Ed. Forense Universitária, 1981.

BAUMAN, Zygmunt. From Pilgrim to Tourist - or a Short History of Identity. In: HALL, Stuart; GAY, Paul Du. Questions of Cultural Identity. London: Sage Publications, 2003, pp. 18-36.

BERTRAND, Denis. Caminhos da Semiótica Literária. Trad. de Ivã Carlos Lopes (Coord.) Bauru, SP: EDUSC, 2003.

CANDIDO, Antonio. A timidez do romance. In: CANDIDO, Antonio. A educação pela noite. 2 ed. São Paulo: Ática, 1989, p.82-99.

CHIARELLI, Stefania. Vidas em trânsito - As ficções de Samuel Rawet e Milton Hatoum. São Paulo: Annablume, 2007.

GALlAGHER, Catherine. "Ficção". In: MORETTI, Franco (org.). A cultura do romance. Trad. Denise Bottmann. São Paulo: Cosac Naif, 2009, p. 629-658.

GENETTE, Gerard. Discurso da narrativa. 3. ed. Trad. Fernando Cabral Martins. Lisboa: Vega, 1975. 
HALL, Stuart. A identidade cultural na pós-modernidade. 11. ed. Trad. Tomáz Tadeu da Silva e Guacira Lopes Louro. Rio de Janeiro: DP \&A, 2006.

; SOVIK, Liv (Org.). Da diáspora: Identidades e Mediações Culturais. Tradução de Adelaine La Guardia Resende [et al]. Belo Horizonte: Editora UFMG; Brasília, Editora da UNESCO no Brasil, 2003.

HATOUM, Milton. Dois Irmãos. São Paulo: Companhia das Letras, 2007.

LE GOFF, Jacques. Memória*. In: -----. História e Memória. Trad. Bernardo Leitão. 5 ed. Campinas, SP: Editora da Unicamp,2003, p. 417-476.

PELLEGRINI, Tânia. "Milton Hatoum e o regionalismo revisitado". Luso-Brazilian Review, Milwalkee, Wisconsin, USA, v. 41, n. 1, p.121-138, 2004. Disponibilidade em: http://muse.jhu.edu/journals/luso-brazilian_review/v041/41.1pellegrini01.html. Acesso em: 08 Out. 2010. p. 121-138.

RICEUR, Paul. A memória, a história, o esquecimento. Trad. Alain François [et al.]. Campinas, SP: Editora da Unicamp, 2007.

ROSSI, Paolo. O passado, a memória e o esquecimento. Trad. de Nilson Moulin. São Paulo, Editora UNESP, 2010.

SARLO, Beatriz. "Crítica do testemunho: sujeito e experiência". In: ------. Tempo passado: cultura da memória e guinada subjetiva. Trad. de Rosa Freire D’Aguiar. São Paulo: Companhia das Letras; Belo Horizonte: UFMG, 2007, p. 23-44.

TELAROLLI, Sylvia. Memória e identidade nos romances de Milton Hatoum. Revista Fikr, São Paulo, n.2, 2010. Disponibilidade em: http://www.miltonhatoum.com.br/sobre-autor/memoria-eidentidade-nos-romances-de-milton-hatoum-por-sylvia-telarolli. Acesso em: 19 Jan. 2013. 